DOI: 10.38136/jgon.683745

\title{
Gebelikte Yaşanan Distres ile Gebelikteki Yakınmalar ve Yaşam Kalitesi Arasındaki ilişski
}

The Correlation Among Pregnancy-Related Distress and Complaints and Quality of Life during Pregnancy

Fatma Zehra AKPINAR

Serap EJDER APAY ${ }^{2}$
(1) Orcid ID:0000-0003-1038-7723

(1) Orcid ID:000-0003-0978-1993

\author{
${ }^{1}$ Health Ministry, Disaster and Emergency Management Department, Ankara, Turkey \\ ${ }^{2}$ Ataturk University, Faculty of Health Science, Department of Midwifery, Erzurum, Turkey
}

\section{öz}

Amaç: Bu çalışma gebelikte yaşanan distres ile gebelikteki yakınmalar ve yaşam kalitesi arasındaki ilişkinin incelenmesi amacıyla yapılmıştır.

Gereçler ve Yöntem: Araştırma, Ordu il merkezinde bulunan Sağlık Bakanlığı'na bağlı Kadın Doğum ve Çocuk Hastanesi'nde Ekim 2016-Eylül 2018 tarihleri arasında başvurmuş olan araştırmaya alınma kriterlerine uyan 558 gebe ile yürütülmüştür. Veriler; Kişisel Bilgi Formu, Tilburg Gebelikte Distres Ölçeği (TGDÖ), Gebelikteki Yakınmalar ve Yaşam Kalitesine Etkisi Ölçeği (GYYKEÖ) kullanılarak toplanmıştır.

Bulgular: Gebeler TGDÖ'nin Olumsuz Duygulanım alt boyutundan 14.17 \pm 8.04 , Eş Katılımı alt boyutundan $4.27 \pm 3.81$ ve ölçek toplamından $18.44 \pm 7.93$ aldıkları bulunmuştur. Gebeler GYYKEÖ'den ise $48.67 \pm 26.69$ aldıkları saptanmıştır. GYYKEÖ ile TGDÖ'nün Olumsuz Duygulanım alt boyutu ve toplam puan ortalamaları arasında negatif yönde zayıf bir ilişki olduğu saptanmıştır (sırasıyla $r=-0.209, p=0.000 ; r=-0.129, p=0.002$ ). GYYKEÖ ile TGDÖ'nün Eş Katılımı alt boyutu arasında pozitif yönde zayıf bir ilişki olduğu görülmüştür ( $p=0.001$ ).

Sonuç: Gebelerin distres açısından risk altında olmadıkları, yaşam kalitelerinin iyi olduğu bulunmuştur. Ayrıca gebelikte distres arttıkça yaşam kalitesinin de azaldığı saptanmıştır.

Anahtar Kelimeler: Distres, gebe, ebe, gebelikte yakınmalar, yaşam kalitesi.

\section{GíRiş}

Gebelik fizyolojik ve doğal bir süreç. olmasına rağmen; hem fetüsün büyüme ve gelişmesi hem de gebelik ve doğum esnasında olası risklerin önlenmesi için bu süreçte anne vücudunda bir takım değişiklikler meydana gelmektedir $(1,2)$. Normal

\section{ABSTRACT}

Aim: The purpose of this study is to examine the correlation among pregnancy-related distress and complaints and the quality of life during pregnancy.

Material and method: The study was conducted with 558 pregnant women, who met the inclusion criteria and came to the Maternity and Children Hospital affiliated with the Ministry of Health in city center of Ordu between October 2016 and September 2018. The data were collected through Personal Information Form, Tilburg Pregnancy Distress Scale (TPDS), and the Scale for Complaints during Pregnancy and its Effects on Quality of Life (SCPEQL).

Results: It was found that the pregnant women had a score of $14.17 \pm 8.04$ from the negative affect subscale of TPDS, $4.27 \pm 3.81$ from its subscale of partner involvement; and $18.44 \pm 7.93$ from the overall scale. On the other hand, it was revealed that the pregnant women received a score of $48.67 \pm 26.69$ from the SCPEQL (respectively $r=-0.209, p=0.000 ; r=-0.129, p=0.002$ ).. A weak negative correlation was found between the negative affect subscale and total mean scores of TPDS and SCPEQL. A positive weak correlation was observed between SCPEQL and the partner involvement subscale of TPDS $(p=0.001)$.

Conclusion: It was found that the pregnant women were not under risk in terms of distress and their quality of life was high. In addition, it was determined that distress levels increased during pregnancy, the quality of life decreased as well.

Key Words: Distress, pregnany, midwifery, complaints, quality of life.

olarak kabul edilen bu fizyolojik değişiklikler hormonlar aracılığıyla oluşmaktadır. Meydana gelen bu değişiklikler hakkında bilgi sahibi olunması ortaya çıkabilecek patolojik durumların erken tanısında önem arzetmektedir $(3,4)$. Gebelik süresinde ortaya çıkan bu fizyolojik değişikliklere bağlı olarak birtakım yakınmalar görülebilmektedir (5). Bu değişiklikler trimesterlere 
ve her gebeye göre farklılık gösterirken neden olduğu yakınmalarda gebenin günlük yaşam aktivitelerini ve beraberinde yaşam kalitesinin etkilemektedir $(5,6)$.

Gebelik sürecini primer yaşayan kişi kadın olsa da eş ve aile üyeleri de hem süreçten etkilenen hem de sürece birtakım etkileri olan bireylerin başında gelirler (6). Anne adayları gebeliği; neşe, kendini gerçekleştirme, mutluluk kaynağı, üretkenliğinin sembolü olarak algılayabilirken; stres, kaygı, endişe ve belirsizlikler dönemi olarakta nitelendirebilirler $(7,8)$. Gebelik dönemi sosyal, ruhsal ve fizyolojik değişiklikler, beden imajının değişmesi, ebeveyn olma kaygısı, sosyal destek eksikliği gibi birçok faktör bağlamında psikolojik distres ile ilişkili hale gelmektedir (9). Psikolojik distres klinik açıdan depresyon, anksiyete ya da stress olarak tanımlanabilir $(7,10,11)$. Gebeliğe bağlı ortaya çıkan fiziksel ve psikolojik yakınmalarla yaşam kalitesi etkilenen gebenin baş etmesi zorlaşmaktadır. Gebelik döneminde ortaya çıkan ruhsal sıkıntılar tedavi edilmez ise, kaygı ve depresyon olarak karşımıza çıkabilmektedir (12). Araştırmalar antenatal dönemde annede yüksek dereceli duygusal sıkıntının, doğum ile ilişkili komplikasyonları artırdığı ve yenidoğan sağlığını olumsuz etkilediğini, göstermektedir (13-15). Geçmişte araştırmalar genellikle doğum sonu postpartum dönemde yaşanan depresyona odaklıyken günümüzde doğum öncesi psikolojik distrese ilişkin faktörlerden söz edilmeye başlanmıştır $(7,16,17)$. Gebelikte distres ile ilgili yapılan çalışmalara bakıldığında gebelerin distres yaşama durumlarının değişik aralıkta olduğu görülmektedir. $(7,18-21)$.

Gebelik sürecinde annenin yaşam kalitesini etkileyecek her türlü sorunun erken tanılanıp tedavi edilmesi son derece önemlidir (7-14). Huizink ve ark. çalışmasında genel anksiyeteden farklı olarak gebelikte yaşanan anksiyetenin gebelik süresince yaşanan nöroendokrin değişiklikler ve doğum sonuçları ile ilişkili olduğunu bildirmişlerdir (15). Dolayısıyla gebelik boyunca yaşanan psikolojik distresin neden olan etmenlerin analizi bu açıdan önem arz etmektedir. Antenatal dönemde yaşanan psikolojik distres anne ve bebek sağıı̆ını etkileyen tedavi edilmesi gereken bir durumdur (7-21). Ebeler gebeler ile yakından ilgilenen, takip eden ve sorunları belirleyen ve tedavisinde görev alan kişilerdir. Ebelerin kadınların sağıklı bir gebelik süreci geçirebilmelerine doğrudan ve önemli katkıları vardır. Distres, gebelikteki yakınmalar ve yaşam kalitesi gebelik sürecinde değişkenlik göstermekte olup ebelerin bu değişkenlikleri değerlendirmesi, erken önlem alma ve çözüm bulma sürecine katkıda bulunması gerekmektedir.

Literatür incelendiğinde gebelerin yaşadığı distresin olağan ya- kınmalar ve yaşam kalitesi üzerine etkisini inceleyen çalışmaya rastlanılmamıştır. Bu nedenle gebelikte yaşanan distres ve gebelikteki yakınmalar-yaşam kalitesi arasındaki ilişkinin incelenmesi amacıyla bu çalışma gerçekleştirilmiştir.

\section{GEREÇLER VE YÖNTEM}

Tanımlayıcı ve ilişki arayıcı nitelikte olan araşıırma, Ordu il merkezinde bulunan Sağlık Bakanlığı'na bağlı Kadın Doğum ve Çocuk Hastanesi'nde Ekim 2016 - Eylül 2018 tarihleri arasında yapıımıştır. Araştırmada örneklem seçimine gidilmeksizin Ekim 2016-Haziran 2017 tarihler arasında araştırmaya alınma kriterlerine uyan ve araştırmaya katılmaya gönüllü olan gebeler araştırmanın örneklemini oluşturmaktadır. Araştırmanın örneklemi ise belirtilen tarihlerde araştırmaya alınma kriterlerine uyan 558 gebe araştırmanın örneklemini oluşturmuştur.

Araştırmaya Alınma Kriterleri:

İletişim problemi olmayan,

En az ilköğretim mezunu olan,

Gebelik haftası 12 ve üzeri olan,

Kendisinde ve bebeğinde herhangi bir risk faktörü olmayan gebeler araştırmanın kriterlerini oluşturmaktadır.

Araştırma verilerinin toplanmasında; Kişisel Bilgi Formu, Tilburg Gebelikte Distres Ölçeği, Gebelikteki Yakınmalar ve Yaşam Kalitesine Etkisi Ölçeği kullanılmıştır.

Kişisel Bilgi Formu: Form gebelerin; tanıtıcı ve obstetrik özelliklerini belirleyecek toplam 13 sorudan oluşmaktadır.

Tilburg Gebelikte Distres Ölçeği (TGDÖ): Pop ve ark. tarafından gebelikteki distresin belirlenmesi için geliştirilmiştir (22). Türkçe geçerlilik ve güvenirlik çalışması Çapık ve Pasinlioğlu tarafından yapılmıştır (23). Ölçek 12 hafta ve üzeri gebeliği olanlara uygulanmaktadır. Ölçek toplam 16 maddeden oluşmaktadır. Ölçek 4'lü likert şeklinde derecelendirilmiştir. Ölçeğin toplamından alınabilecek en düşük puan 0 , en yüksek puan 48 'tir. Ölçeğin "Olumsuz Duygulanım" ve "Eş Katılımı" olmak üzere iki alt boyutu bulunmaktadır. Ölçeğin kesme noktasına göre alınan toplam puanın 28 ve üzerinde olması distres (depresyon, anksiteye, stres) açısından risk altında olan gebelerin tanılanmasını sağlamaktadır. Ölçeğin geçerlilik-güvenirlik çalışmasında ölçek iç tutarlıık değeri 0.83 olarak bulunmuş (23) olup bu çalışmada ise 0.80 olarak tespit edilmiştir.

Olumsuz Duygulanım Alt Boyutu: Bu alt boyut 11 maddeden oluşmaktadır. Bu alt boyuttan alınabilecek en düşük puan 0 , en yüksek puan 33'tür.

Eş Katıımı Alt Boyutu: Bu alt boyut 5 maddeden oluşmaktadır. 
Bu alt boyuttan alınabilecek en düşük puan 0 , en yüksek puan $15^{\prime}$ tir.

Gebelikteki Yakınmalar ve Yaşam Kalitesine Etkisi Ölçeği (GYYKEÖ): Foxcroft ve ark. tarafından gebelikte yaşanabilecek yakınmaların günlük yaşamı nasıl etkilediğinin sağlık profosyonelleri tarafından değerlendirilmesi için hazırlanmış bir ölçektir (24). Türkçe geçerlilik ve güvenirlik çalışması Özorhan ve Pasinlioğlu tarafından yapıımıştı (25). Ölçekten alınan puanların yükselmesi gebelerin yaşam kalitelerinin düşük olduğunu ifade etmektedir. Ölçeğin geçerlilik-güvenirlik çalışmasında Cronbach Alfa değeri 0.91 olarak bulunmuştur (25). Bu çalışmada ölçeğin Cronbach Alfa değeri 0.92 olarak bulunmuştur.

Veriler Ekim 2016- Haziran 2017 tarihleri arasında yüz yüze görüşme tekniği ile araştırmacılar tarafından toplanmıştır. Veriler SPSS 21 paket programında değerlendirilmişsir. Verilerin değerlendirilmesinde; tanıtıcı özellikler için yüzdelik, ortalama, standart sapma; ölçekler arasındaki ilişkiyi değerlendirmek için pearson korelasyon; ölçek puan ortalamasını etkileyen faktörlerin analizinde ANOVA ve t testi kullanılmıştır. Araştırma, XX II Sağlık Müdürlüğü'ne bağlı Kadın Doğum ve Çocuk Hastalıkları Hastanesi ile sınırlıdır. Araştırma sonuçları çalışmaya katılmayı kabul eden gruba genellenebilir. Araştırmaya başlamadan önce XXXX Üniversitesi Sağlık Bilimleri Fakültesi Etik kurulundan onay (No:2016/07/14) ve Kadın Doğum ve Çocuk Hastalıkları Hastanesinden resmi izin (04.10.2016 tarih ve E.1600225872 sayı) alınmıştır.

\section{BULGULAR}

Gebelerin tanıtıcı özelliklerinin dağııımı Tablo 1'de verilmiştir. Araştırmaya alınan gebelerin \%51.3'ü 18-27 yaş arasında, \%36'sı lise mezunu, \%75.3'ünün çalışmadığı, \%75.5'nin il merkezinde yaşadığı, \%40.1'nin gelir durumu algısının giderine denk olduğu, \%71.1'nin çekirdek ailede yaşadığı, \%62.7'sinin 1-5 yıldır evli olduğu, \%36.9'nun ilk gebeliği olduğu ve \%41.6'sının hiç doğum yapmadığı saptanmıştır.

Tablo 1. Gebelerin Tanıııcı Özelliklerinin Dağııımı

\begin{tabular}{lcc}
\hline Özellikler & Sayı & Yüzde \\
\hline Yaş & & \\
$18-27$ & 286 & 51.3 \\
$28-37$ & 230 & 41.2 \\
38 ve & 42 & 7.5 \\
\hline Eğitim & & \\
Illkokul & 95 & 17.0 \\
Ortaokul & 136 & 24.4 \\
Lise & 201 & 36.0 \\
Üniversite & 126 & 22.6 \\
\hline
\end{tabular}

Çalışma Durumu

Calışan

Çalışmayan 75.3

Yaşanılan Yer

ilçe

$52 \quad 9.3$

$85 \quad 15.2$

il

Gelir Durumu Algısı

Gelirim giderimden az

$147 \quad 26.3$

Gelirim giderime denk

$224 \quad 40.1$

Gelirim giderimden fazla

$187 \quad 33.6$

Aile Tipi

$\begin{array}{lll}\text { Çekirdek } & 397 & 71.1\end{array}$

Geniş

$161 \quad 28.9$

Evlilik Yılı

$1-5 \mathrm{yı}$

350

62.7

6-10 yıl

11 yıl ve $\uparrow$

$91 \quad 16.3$

Eş Yaş

21-27 yaş

277

49.7

28- 34 yaş

35 ve

123

22.0

Eş Eğitim

ilkokul

$87 \quad 15.6$

Ortaokul

102

18.3

Lise

206

36.9

Üniversite

163

29.2

Eş Çalışma Durumu

Çalışan

435

78.0

Çalışmayan

$123 \quad 22.0$

Gebelik Sayısı

1

206

36.9

2

$144 \quad 25.8$

3

$81 \quad 14.5$

4 ve $\uparrow$

$127 \quad 22.8$

Doğum Sayısı

0

3 ve $\uparrow$

$119 \quad 21.4$ 


\begin{tabular}{lcc}
\hline Yaşayan Çocuk Sayısı & & \\
0 & 234 & 41.9 \\
1 & 149 & 26.7 \\
2 & 91 & 16.3 \\
3 ve $\uparrow$ & 84 & 15.1 \\
\hline
\end{tabular}

Gebelerin TGDÖ ve GYYKEÖ'den alınan minimum-maksimum değerleri ve puan ortalamalarının dağılımı (Tablo 2) incelendiğinde; TGDÖ'nün Olumsuz Duygulanım alt boyutundan 14.17 \pm 8.04 , Eş Katılımı alt boyutundan $4.27 \pm 3.81$ ve ölçek toplamından $18.44 \pm 7.93$ aldıkları bulunmuştur. Gebeler GYYKEÖ'den ise $48.67 \pm 26.69$ aldıkları saptanmıştır.

Tablo 2. Gebelerin TGDÖ ve GYYKEÖ'den Alınan Min-Max ve Puan Ortalamalarının Dağııımı

\begin{tabular}{llccc}
\hline \multicolumn{2}{l}{ Ölçekler } & Min & Max & \pm SS \\
\hline \multirow{2}{*}{$: 0$} & Olumsuz Duygulanım & 0 & 33 & $14.17 \pm 8.04$ \\
\cline { 2 - 5 } & Eş Katılımı & 0 & 15 & $4.27 \pm 3.81$ \\
\cline { 2 - 5 } & Toplam & 0 & 36 & $18.44 \pm 7.93$ \\
\hline \multicolumn{2}{l}{ GYYKEÖ } & 0 & 166 & $48.67 \pm 26.69$ \\
\hline
\end{tabular}

Gebelerin TGDÖ ve GYYKEÖ puan ortalamaları arasındaki ilişkinin dağıımı Tablo 3'de verilmiştir. GYYKEÖ ile TGDÖ'nün Olumsuz Duygulanım alt boyutu ve toplam puan ortalamaları arasında negatif yönde zayıf bir ilişki olduğu saptanmıştır. GYYKEÖ ile TGDÖ'nün Eş Katııımı alt boyutu arasında pozitif yönde zayıf bir ilişki olduğu görülmüştür.

Tablo 3. Gebelerin TGDÖ ve GYYKEÖ Puan Ortalamaları Arasındaki İlişkinin Dağııımı

\begin{tabular}{|c|c|c|c|}
\hline Ölçekler & & & GYYKEÖ \\
\hline \multirow{6}{*}{ 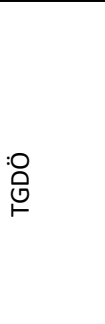 } & Olumsuz Duygulanım & $r=$ & $-0.209 * *$ \\
\hline & & $p=$ & 0.000 \\
\hline & Eş Katılımı & $r=$ & $0.172^{* *}$ \\
\hline & & $p=$ & 0.000 \\
\hline & Toplam & $r=$ & $-0.129 * *$ \\
\hline & & $p=$ & 0.002 \\
\hline
\end{tabular}

\section{$\bar{p}<0.001$}

Gebelerin tanıtıcı özelliklerine göre TGDÖ puan ortalamalarının karşılaştırıması (Tablo 4) incelendiğinde; gebelerin gelir durumu, evlilik yılı, eş yaş, eş eğitim, eş çalışma durumu, gebelik, doğum, yaşayan çocuk sayısının Olumsuz Duygulanım alt boyutu puan ortalamalarını etkilediği bulunmuştur.

Gelir durumu giderinden az olan gebelerin TGDÖ Olumsuz Duygulanım alt boyutu puan ortalaması $11.97 \pm 7.18$, geliri gide- rine denk olanların $13.37 \pm 7.90$, geliri giderinden fazla olanların $16.27 \pm 8.21$ olduğu bulunmuştur. Grupların puan ortalamaları arasındaki fark geliri fazla olanların aleyhine istatistiksel olarak yüksek olduğu saptanmıştır $(p<0.05)$. Gebelerin gelir düzeyi arttıkça ölçek puan ortalamasının da artığı saptanmıştır.

Evlilik yılı 1-5 yıl arasında olanların TGDÖ Olumsuz Duygulanım alt boyutu puan ortalaması $15.40 \pm 8.18,6-10$ yıl olanların $12.42 \pm 7.80,11$ ve daha fazla olanların ise $11.65 \pm 6.75$ olduğu belirlenmiştir. Grupların puan ortalamaları arasındaki fark evlilik yılı fazla olanların lehine istatistiksel olarak düşük olduğu saptanmıştır $(p<0.05)$. Gebelerin evlilik yılı artıkça TGDÖ Olumsuz Duygulanım alt boyutu puan ortalamasının azaldığı da saptanmıştır.

Gebelerin eşlerinin yaşına göre TGDÖ Olumsuz Duygulanım alt boyutu puan ortalamalarının karşılaştıııması incelendiğinde; eşlerin yaşı artıkça puan ortalamasının (sırasıyla 15.40 \pm 8.21 , $14.15 \pm 7.48,11.41 \pm 7.71$ ) düştüğü ve grupların puan ortalamaları arasındaki fark genç eşlerin aleyhine istatistiksel olarak yüksek olduğu görülmüştür $(p<0.05)$.

Eşi ilkokul mezunu olan gebelerin TGDÖ Olumsuz Duygulanım alt boyutu puan ortalaması $14.56 \pm 8.35$, ortaokul mezunu olanların $15.93 \pm 8.07$, lise mezunu olanların $14.91 \pm 7.63$ ve üniversite mezunu olanların $11.26 \pm 7.32$ olarak bulunmuştur. Eş eğitim durumuna göre grupların puan ortalamaları arasındaki fark üniversite mezunlarının lehine istatistiksel olarak düşük olduğu saptanmıştır $(p<0.05)$.

Eşi çalışan gebelerin çalışmayanlara göre TGDÖ Olumsuz Duygulanım alt boyutu puan ortalamasının daha yüksek olduğu ve puan ortalamaları arasındaki fark çalışanların aleyhine istatistiksel olarak yüksek olduğu belirlenmiştir $(p<0.05)$.

Gebelik sayısı bir olan gebelerin TGDÖ Olumsuz Duygulanım alt boyutu puan ortalaması $15.70 \pm 8.36$, iki olanların $12.60 \pm 8.22$, üç olanların $12.74 \pm 7.84$, dört ve üstünde olanların ise $14.37 \pm 6.95$ olduğu ve puan ortalamaları arasındaki farkın istatistiksel olarak anlamlı olduğu bulunmuştur $(p<0.05)$.

Hiç doğum yapmamış gebelerin TGDÖ Olumsuz Duygulanım alt boyutu puan ortalaması $15.80 \pm 8.29$, bir doğum yapanların $11.72 \pm 8.06$, iki doğum yapanların $12.83 \pm 7.84$, üç ve daha fazla doğum yapanların $14.42 \pm 6.89$ olduğu görülmüştür. Grupların puan ortalamaları arasındaki fark hiç doğum yapmayanların aleyhine istatistiksel olarak yüksek olduğu saptanmıştır $(p<0.05)$.

Yaşayan çocuğu olmayan gebelerin TGDÖ Olumsuz Duygulanım alt boyutu puan ortalaması $15.76 \pm 8.31$, tek çocuğu olan- 
ların 12.42 \pm 7.88 , iki çocuğu olanların $11.75 \pm 7.03$, üç ve daha fazla çocuğa sahip olanların $15.45 \pm 7.42$ olduğu görülmüş ve puan ortalamaları arasındaki fark yaşayan çocuğu olmayan gebelerin aleyhine istatistiksel olarak yüksek olduğu bulunmuştur $(p<0.05)$.

Gebelerin tanıtıcı özelliklerine göre TGDÖ Eş Katıımı alt boyutu puan ortalamalarının karşılaştıııması (Tablo 4) incelendiğinde; gebelerin yaşı hariç geri kalan tüm değişkenlerin puan ortalamaları arasındaki farkın istatistiksel olarak anlamlı olduğu bulunmuştur $(p<0.05)$.

Gebelerin tanıtıcı özelliklerine göre TGDÖ toplam puan ortalamalarının karşılaştırıması (Tablo 4) incelendiğinde; köyde yaşayan gebelerin puan ortalaması $19.17 \pm 8.25$, ilçede yaşayanların $20.43 \pm 8.23$, il merkezinde yaşayanların $17.95 \pm 7.77$ olduğu ve puan ortalamaları arasındaki fark ilde yaşayanların lehine istatistiksel olarak düşük olduğu bulunmuştur $(p<0.05)$.

Evlilik yılı 1-5 yıl arasında olanların TGDÖ toplam puan ortalaması 19.24 $\pm 7.99,6-10$ yıl olanların 16.62 $\pm 7.82,11$ ve daha fazla olanların ise $17.70 \pm 7.42$ olduğu belirlenmiştir. Grupların puan ortalamaları arasındaki fark evlilik yılı çok olanların lehine istatistiksel olarak düşük olduğu saptanmıştır $(p<0.05)$.

Gebelerin eşlerinin yaşına göre TGDÖ toplam puan ortalamalarının karşılaştırıması incelendiğinde; eşlerin yaşı arttıkça puan ortalamasının (sırasıyla 19.33 $\pm 7.88,18.37 \pm 7.65,16.51 \pm 8.09$ ) düştüğü ve grupların puan ortalamaları arasındaki fark 35 yaş ve üstünde olanların lehine istatistiksel olarak düşük olduğu görülmüştür $(p<0.05)$.

Eşi ilkokul mezunu olan gebelerin TGDÖ toplam puan ortalaması $19.09 \pm 8.24$, ortaokul mezunu olanların $19.60 \pm 7.73$, lise mezunu olanların $18.76 \pm 7.88$ ve üniversite mezunu olanların $16.42 \pm 7.71$ olarak bulunmuştur. Eş eğitim durumuna göre grupların puan ortalamaları arasındaki fark üniversite mezunu olanların lehine istatistiksel olarak düşük olduğu saptanmıştır $(p<0.05)$.

Eşi çalışan gebelerin TGDÖ toplam puan ortalamasının $18.98 \pm 7.80$, çalışmayanların $16.51 \pm 8.09$ olduğu ve puan ortalamaları arasındaki fark çalışmayanların lehine istatistiksel olarak düşük olduğu belirlenmiştir $(p<0.05)$.

Gebelik sayısı bir olan gebelerin TGDÖ toplam puan ortalaması $19.21 \pm 7.77$, iki olanların $16.62 \pm 8.55$, üç olanların $17.03 \pm 7.59$, dört ve üstünde olanların ise $20.14 \pm 7.15$ olduğu bulunmuş ve aradaki fark gebelik sayısı 4 ve daha fazla olanların aleyhine istatistiksel olarak yüksek olduğu belirlenmiştir.

Hiç doğum yapmamış gebelerin TGDÖ toplam puan ortala- ması 19.38 $\pm 7.84,1$ doğum yapanların 15.72 \pm 8.35 , 2 doğum yapanların $17.46 \pm 7.79$ ve 3 ve daha fazla doğum yapanların $20.04 \pm 7.04$ olduğu görülmüştür. Grupların puan ortalamaları arasındaki fark 3 ve daha fazla doğum yapanların aleyhine istatistiksel olarak yüksek olduğu saptanmıştır $(p<0.05)$.

Yaşayan çocuğu olmayan gebelerin TGDÖ toplam puan ortalaması 19.32 \pm 7.86 , tek çocuğu olanların $16.61 \pm 8.02$, iki çocuğu olanların $16.17 \pm 7.51$, üç ve daha fazla çocuğa sahip olanların $21.69 \pm 6.93$ olduğu görülmüş ve puan ortalamaları arasındaki fark 3 ve daha fazla çocuğu olanların aleyhine istatistiksel olarak yüksek olduğu bulunmuştur $(p<0.05)$.

Tablo 4. Gebelerin Tanıtıcı Özelliklerine Göre TGDÖ Puan Ortalamalarının Karşılaştıııması

\begin{tabular}{|c|c|c|c|}
\hline \multirow{3}{*}{ Özellikler } & \multicolumn{2}{|c|}{ ALT BOYUTLAR } & \multirow{3}{*}{$\begin{array}{c}\text { Toplam Puan } \\
\pm S S\end{array}$} \\
\hline & $\begin{array}{l}\text { Olumsuz Duy- } \\
\text { gulanım }\end{array}$ & Eş Katılımı & \\
\hline & & $\pm S S$ & \\
\hline \multicolumn{4}{|l|}{ Yaş } \\
\hline $18-27$ & $14.65 \pm 7.97$ & $4.05 \pm 3.51$ & $18.70 \pm 8.16$ \\
\hline $28-37$ & $13.36 \pm 8.10$ & $4.47 \pm 4.03$ & $17.83 \pm 7.62$ \\
\hline 38 ve & $15.33 \pm 7.95$ & $4.61 \pm 4.47$ & $19.95 \pm 7.88$ \\
\hline Test ve $p$ değeri & $F=2.10, p=0.12$ & $\begin{array}{l}F=0.95 \\
p=0.38\end{array}$ & $\begin{array}{l}F=1.58, \\
p=0.20\end{array}$ \\
\hline \multicolumn{4}{|l|}{ Eğitim } \\
\hline ilkokul & $13.17 \pm 6.92$ & $6.56 \pm 4.26$ & $19.74 \pm 7.42$ \\
\hline Ortaokul & $14.46 \pm 8.19$ & $4.78 \pm 3.67$ & $19.25 \pm 8.60$ \\
\hline Lise & $13.85 \pm 8.31$ & $3.76 \pm 3.48$ & $17.62 \pm 7.84$ \\
\hline Üniversite & $15.11 \pm 8.19$ & $2.78 \pm 3.18$ & $17.89 \pm 7.54$ \\
\hline Test ve $p$ değeri & $\mathrm{F}=1.22, \mathrm{p}=0.30$ & $\begin{array}{l}F=22.16, \\
p=0.000\end{array}$ & $\begin{array}{l}F=2.25, \\
p=0.08\end{array}$ \\
\hline \multicolumn{4}{|l|}{ Çalışma Durumu } \\
\hline Çalışan & $15.15 \pm 8.70$ & $2.35 \pm 2.96$ & $17.50 \pm 7.88$ \\
\hline Çalışmayan & $13.85 \pm 7.79$ & $4.90 \pm 3.85$ & $18.75 \pm 7.93$ \\
\hline Test ve $p$ değeri & $t=1.65, p=0.09$ & $\begin{array}{c}t=7.10 \\
p=0.000\end{array}$ & $\begin{array}{l}t=1.59, \\
p=0.11\end{array}$ \\
\hline \multicolumn{4}{|l|}{ Yaşanılan Yer } \\
\hline Köy & $13.30 \pm 8.02$ & $5.86 \pm 4.31$ & $19.17 \pm 8.25$ \\
\hline İlçe & $15.57 \pm 7.96$ & $4.85 \pm 4.13$ & $20.43 \pm 8.23$ \\
\hline ì & $13.99 \pm 8.04$ & $3.95 \pm 3.61$ & $17.95 \pm 7.77$ \\
\hline Test ve $p$ değeri & $F=1.70, p=0.18$ & $\begin{array}{l}F=7.16, \\
p=0.001\end{array}$ & $\begin{array}{l}F=3.75 \\
p=0.02\end{array}$ \\
\hline
\end{tabular}


Gelir Durumu Algısı

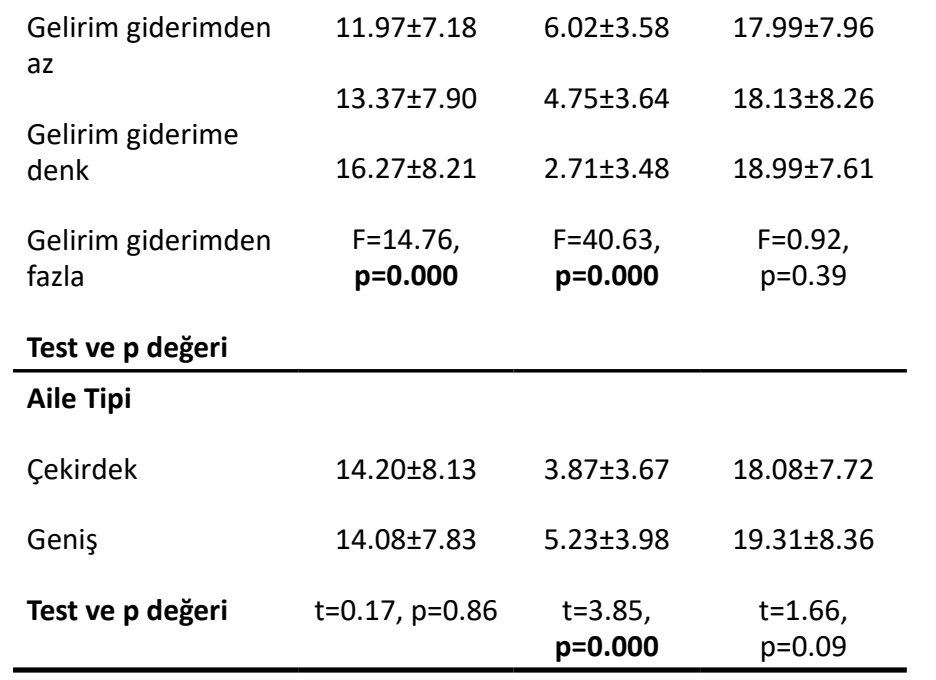

\begin{tabular}{lccc}
\hline Evlilik Yılı & & & \\
$1-5$ yıl & $15.40 \pm 8.18$ & $3.83 \pm 3.53$ & $19.24 \pm 7.99$ \\
$6-10$ yıl & $12.42 \pm 7.80$ & $4.19 \pm 3.87$ & $16.62 \pm 7.82$ \\
11 yıl ve $\uparrow$ & $11.65 \pm 6.75$ & $6.04 \pm 4.25$ & $17.70 \pm 7.42$ \\
Test ve $\mathbf{p}$ değeri & $\mathrm{F}=11.76$, & $\mathrm{F}=12.67$, & $\mathrm{F}=5.33$, \\
& $\mathbf{p}=\mathbf{0 . 0 0 0}$ & $\mathbf{p}=\mathbf{0 . 0 0 0}$ & $\mathbf{p}=\mathbf{0 . 0 0 5}$ \\
\hline Eş Yaş & & & \\
& & & \\
$21-27$ yaş & $15.40 \pm 8.21$ & $3.93 \pm 3.70$ & $19.33 \pm 7.88$ \\
$28-34$ yaş & $14.15 \pm 7.48$ & $4.21 \pm 4.01$ & $18.37 \pm 7.65$ \\
35 ve $\uparrow$ & $11.41 \pm 7.71$ & $5.09 \pm 3.66$ & $16.51 \pm 8.09$ \\
Test ve $\mathbf{p}$ değeri & $\mathrm{F}=10.85$, & $\mathrm{F}=4.03$, & $\mathrm{F}=5.50$, \\
& $\mathbf{p}=\mathbf{0 . 0 0 0}$ & $\mathbf{p}=\mathbf{0 . 0 1}$ & $\mathbf{p}=\mathbf{0 . 0 0 4}$ \\
\hline
\end{tabular}

\begin{tabular}{lccc} 
& $\mathrm{p}=0.000$ & $\mathrm{p}=0.01$ & $\mathrm{p}=0.004$ \\
\hline Eş Eğitim & & & \\
İlkokul & $14.56 \pm 8.35$ & $4.52 \pm 3.69$ & $19.09 \pm 8.24$ \\
Ortaokul & $15.93 \pm 8.07$ & $3.66 \pm 3.75$ & $19.60 \pm 7.73$ \\
Lise & $14.91 \pm 7.63$ & $3.85 \pm 4.11$ & $18.76 \pm 7.88$ \\
Üniversite & $11.26 \pm 7.32$ & $5.15 \pm 3.57$ & $16.42 \pm 7.71$ \\
Test ve $\mathrm{p}$ değeri & $\mathrm{F}=11.33$, & $\mathrm{F}=5.35$, & $\mathrm{F}=5.34$, \\
& $\mathrm{p}=\mathbf{0 . 0 0 0}$ & $\mathrm{p}=\mathbf{0 . 0 0 1}$ & $\mathbf{p}=\mathbf{0 . 0 0 1}$ \\
\hline Eş Çalışma Durumu & & & \\
Çalışan & & & \\
Çalışmayan & $14.95 \pm 7.97$ & $4.03 \pm 3.82$ & $18.98 \pm 7.80$ \\
& $11.41 \pm 7.71$ & $5.09 \pm 3.66$ & $16.51 \pm 8.09$ \\
Test ve $\mathrm{p}$ değeri & $\mathrm{t}=4.37$, & $\mathrm{t}=2.74$, & $\mathrm{t}=3.08$, \\
& $\mathrm{p}=\mathbf{0 . 0 0 0}$ & $\mathbf{p}=\mathbf{0 . 0 0 6}$ & $\mathrm{p}=\mathbf{0 . 0 0 2}$ \\
\hline
\end{tabular}

\section{Gebelik Sayısı}

\begin{tabular}{lccc}
1 & $15.70 \pm 8.36$ & $3.50 \pm 3.48$ & $19.21 \pm 7.77$ \\
2 & $12.60 \pm 8.22$ & $4.02 \pm 3.33$ & $16.62 \pm 8.55$ \\
3 & $12.74 \pm 7.84$ & $4.29 \pm 3.70$ & $17.03 \pm 7.59$ \\
4 ve $\uparrow$ & $14.37 \pm 6.95$ & $5.77 \pm 4.45$ & $20.14 \pm 7.15$ \\
Test ve $\mathbf{p}$ değeri & $\mathrm{F}=5.31$, & $\mathrm{F}=9.97$, & $\mathrm{F}=6.14$, \\
& $\mathrm{p}=\mathbf{0 . 0 0 1}$ & $\mathbf{p}=\mathbf{0 . 0 0 0}$ & $\mathrm{p}=\mathbf{0 . 0 0 0}$ \\
\hline Doğum Sayısı & & & \\
0 & $15.80 \pm 8.29$ & $3.58 \pm 3.49$ & $19.38 \pm 7.84$ \\
1 & $11.72 \pm 8.06$ & $3.99 \pm 3.29$ & $15.72 \pm 8.35$ \\
2 & $12.83 \pm 7.84$ & $4.62 \pm 3.98$ & $17.46 \pm 7.79$ \\
3 ve $\uparrow$ & $14.42 \pm 6.89$ & $5.62 \pm 4.37$ & $20.04 \pm 7.04$ \\
Test ve $\mathrm{p}$ değeri & $\begin{array}{l}\mathrm{F}=7.95, \\
\mathrm{p}=\mathbf{0 . 0 0 0}\end{array}$ & $\begin{array}{l}\mathrm{F}=8.29, \\
\mathrm{p}=\mathbf{0 . 0 0 0}\end{array}$ & $\begin{array}{l}\mathrm{F}=8.08, \\
\mathrm{p}=\mathbf{0} .000\end{array}$ \\
\hline
\end{tabular}

Yaşayan Çocuk Sayısı

0

1

2

3 ve $\uparrow$

$15.76 \pm 8.31 \quad 3.55 \pm 3.48 \quad 19.32 \pm 7.86$

$11.75 \pm 7.03 \quad 4.18 \pm 3.43 \quad 16.61 \pm 8.02$

$12.42 \pm 7.88 \quad 4.41 \pm 3.93 \quad 16.17 \pm 7.51$

$15.45 \pm 7.42 \quad 6.23 \pm 4.47 \quad 21.69 \pm 6.93$

$\begin{array}{llll} & F=9.24, & F=10.78, & F=11.39, \\ \text { Test ve } p \text { değeri } & p=0.000 & p=0.000 & p=0.000\end{array}$

Gebelerin tanıtıcı özelliklerine göre GYYKEÖ puan ortalamalarının karşılaştıııması Tablo 5'de sunulmuştur. Gebelerin çalışma durumu, gelir durumu algısı, evlilik yılı, eş yaşı, eş eğitimi, eş çalışma durumu ölçek puan ortalamalarını etkilediği bulunmuştur.

Çalışan gebelerin GYYKEÖ puan ortalamalarının çalışmayan gebelerden daha düşük olduğu ve aradaki farkın istatistiksel olarak anlamlı olduğu bulunmuştur ( $p<0.05)$.

Geliri giderinden az olan gebelerin GYYKEÖ puan ortalaması $54.12 \pm 26.52$, geliri giderine denk olanların $51.22 \pm 28.23$, geliri giderinden fazla olanların $42.96 \pm 24.42$ olduğu puan ortalamaları arasındaki farkın istatistiksel olarak anlamlı olduğu bulunmuştur. Gebelerin gelir durumu algısı iyileştikçe puan ortalamalarının düştüğü görülmüştür.

Çekirdek ailede yaşayan gebelerin puan ortalamasının $(50.09 \pm 27.29)$ geniş ailede yaşayanlardan $(45.18 \pm 24.89)$ daha yüksek olduğu saptanmıştır.

Evlilik yılı 1-5 yıl arasında olanların GYYKEÖ puan ortalaması $46.60 \pm 26.22,6-10$ yıl olanların 50.96 $\pm 26.97,11$ ve daha fazla olanların ise $53.71 \pm 27.51$ olduğu ve puan ortalamaları ara- 
sındaki farkın istatistiksel olarak anlamlı olduğu saptanmıştır $(p<0.05)$. Evlilik yılı arttıkça ölçek puan ortalamasının da artıı̆ı görülmüştür.

Eşi ilkokul mezunu olan gebelerin GYYKEÖ puan ortalaması $31.98 \pm 22.18$, ortaokul mezunu olanların $38.51 \pm 19.85$, lise mezunu olanların $50.37 \pm 20.70$ ve üniversite mezunu olanların $69.36 \pm 26.62$ olarak bulunmuştur. Eş eğitim durumuna göre grupların puan ortalamaları arasındaki farkın istatistiksel olarak anlamlı olduğu ve eğitim seviyesi arttıkça GYYKEÖ puan ortalamasının artı̆̆ı saptanmıştır $(p<0.05)$.

Eşi çalışan gebelerin GYYKEÖ puan ortalamasının $41.72 \pm 22.18$, çalışmayanların $73.26 \pm 26.84$ olduğu ve puan ortalamaları arasındaki farkın istatistiksel olarak anlamlı olduğu belirlenmiştir $(p<0.05)$.

Tablo 5. Gebelerin Tanıtıı Özelliklerine Göre GYYKEÖ Puan Ortalamalarının Karşılaştıııması

\begin{tabular}{|c|c|c|}
\hline \multirow[b]{2}{*}{ Özellikler } & GYYKEÖ & \multirow{2}{*}{$\begin{array}{c}\text { Test ve } p \\
\text { değeri }\end{array}$} \\
\hline & $\pm S S$ & \\
\hline \multicolumn{3}{|l|}{ Yaş } \\
\hline $18-27$ & $48.12 \pm 25.92$ & \multirow[t]{3}{*}{$\begin{array}{l}F=2.10, \\
p=0.12\end{array}$} \\
\hline $28-37$ & $50.63 \pm 28.06$ & \\
\hline 38 ve & $41.73 \pm 23.13$ & \\
\hline \multicolumn{3}{|l|}{ Eğitim } \\
\hline Illkokul & $50.46 \pm 27.26$ & \multirow{4}{*}{$\begin{array}{l}F=2.34, \\
p=0.07\end{array}$} \\
\hline Ortaokul & $51.00 \pm 26.92$ & \\
\hline Lise & $49.67 \pm 27.68$ & \\
\hline Üniversite & $43.23 \pm 23.82$ & \\
\hline \multicolumn{3}{|l|}{ Çalışma Durumu } \\
\hline Çalışan & $41.82 \pm 24.14$ & \multirow[t]{2}{*}{$\begin{array}{c}t=3.51 \\
p=0.000\end{array}$} \\
\hline Çalışmayan & $50.92 \pm 27.13$ & \\
\hline \multicolumn{3}{|l|}{ Yaşanılan Yer } \\
\hline Köy & $49.00 \pm 27.34$ & \multirow{3}{*}{$\begin{array}{l}F=0.08 \\
p=0.91\end{array}$} \\
\hline İlçe & $47.56 \pm 27.43$ & \\
\hline il & $48.86 \pm 26.52$ & \\
\hline \multicolumn{3}{|l|}{ Gelir Durumu Algısı } \\
\hline Gelirim giderimden az & $54.12 \pm 26.52$ & \multirow{3}{*}{$\begin{array}{l}F=9.31 \\
p=0.000\end{array}$} \\
\hline Gelirim giderime denk & $51.22 \pm 28.23$ & \\
\hline Gelirim giderimden fazla & $42.96 \pm 24.42$ & \\
\hline \multicolumn{3}{|l|}{ Aile Tipi } \\
\hline Çekirdek & $50.09 \pm 27.29$ & \multirow[t]{2}{*}{$\begin{array}{l}t=1.97 \\
p=0.04\end{array}$} \\
\hline Geniş & $45.18 \pm 24.89$ & \\
\hline
\end{tabular}

\section{Evlilik Yılı}

$1-5 \mathrm{yl}$

$46.60 \pm 26.22$

6-10 yıl

$50.96 \pm 26.97$

$F=3.13$, $p=0.04$

$53.71 \pm 27.51$

11 yıl ve $\uparrow$

Eş Yaş

21-27 ya

$36.50 \pm 20.70$

28- 34 yaş

$50.88 \pm 21.78$

$F=114.81$,

$73.26 \pm 26.84$

$\mathrm{p}=\mathbf{0 . 0 0 0}$

\section{5 ve $\uparrow$ \\ Eş Eğitim}

İlkokul

$31.98 \pm 22.18$

Ortaokul

$38.51 \pm 19.85$

$F=75.86$,

$50.37 \pm 20.70$

$p=0.000$

Lise

$69.36 \pm 26.62$

Üniversite

Eş Çalışma Durumu

$\begin{array}{lll}\text { Çalışan } & 41.72 \pm 22.18 & \mathrm{t}=13.25, \\ & & \mathbf{p}=\mathbf{0 . 0 0 0}\end{array}$

\section{Gebelik Sayısı}

1

$47.47 \pm 27.97$

2

$48.80 \pm 25.13$

$F=0.32$,

3

$50.85 \pm 24.99$ $\mathrm{p}=0.80$

4 ve $\uparrow$

$49.09 \pm 27.52$

\section{Doğum Sayısı}

0

$47.68 \pm 28.05$

1

$48.69 \pm 24.30$

$F=0.30$,

2

$48.70 \pm 25.39$

$\mathrm{p}=0.82$

3 ve $\uparrow$

$50.57 \pm 27.40$

\section{Yaşayan Çocuk Sayısı}

0

$47.75 \pm 28.06$

1

$48.79 \pm 26.37$

$F=0.20$, 1

2

$50.00 \pm 25.04$ $\mathrm{p}=0.89$

3 ve $\uparrow$

$49.60 \pm 25.39$

Gebelerin TGDÖ kesme noktasına göre dağılımı (Tablo 6) incelendiğinde; gebelerin \%15.1'de distres olduğu, $\% 84.9$ 'da ise distres olmadığı bulunmuştur.

Tablo 6. Gebelerin TGDÖ Kesme Noktasına Göre Dağılımı

\begin{tabular}{lcc}
\hline Kesme Noktası & Sayı & Yüzde \\
\hline Distres Olan & 84 & 15.1 \\
\hline Distres Olmayan & 474 & 84.9 \\
\hline
\end{tabular}




\section{TARTIŞMA}

Gebelikte yaşanan distres ve gebelikteki yakınmalar-yaşam kalitesi arasındaki ilişkinin incelenmesi amacıyla yapılan araştırmadan elde edilen bulgular ilgili literatür ile tartışılmıştır.

Araştırmada gebeler TGDÖ'nün olumsuz duygulanım alt boyutu puan ortalaması $(14.17 \pm 8.04)$ kesme noktasının altında bulunmuştur (Tablo 2). Araştırma bu bulgu yönüyle Çapık ve ark. $(13.64 \pm 6.40)$ ve Bacacı'nın (13.81 \pm 5.69$)$ çalışmasıyla paralellik göstermiştir $(7,20)$. Fakat Özyurt'un $(18.61 \pm 7.86)$ ve Çiltaş'ın (19.66 \pm 6.68$)$ çalışmaları araştırma bulgusundan farklı olarak Olumsuz Duygulanım alt boyutu puan ortalaması kesme noktasına yakın seyretmiştir $(19,21)$. Son trimestirde artan gebelik yükü, yaşanılan fiziksel rahatsızlıklar, doğum korkusu, doğuma dair olumsuz düşüncelerin sıklaşması, doğum içerikli rüyaların görülmesi ve doğumda kendisinin ve bebeğinin sağlığına dair endişeler nedeniyle gebeler olumsuz duygular hissedebilirler.

Eş katılımı alt boyutundan alınan puan ortalaması $(4.27 \pm 3.81)$ ölçeğin kesme noktasından düşük seyretmiştir (Tablo 2). Araştırmanın bu bulgusu Çapık ve ark. (5.22 \pm 3.47$)$, Özyurt'un $(4.57 \pm 3.02)$ ve Çiltaş'ın (3.10 \pm 3.49$)$ çalışması ile paralellik göstermektedir $(7,19,21)$. Bacacı'nın $(6.20 \pm 2.77)$ yapmış olduğu çalışmada ise Eş Katıııı alt boyut puan ortalamasının daha yüksek olduğu görülmüştür (20).

Araştırmada gebelerin TGDÖ toplam puan ortalaması (18.44 \pm 7.93$)$ ölçeğin kesme noktasından düşük bulunmuştur (Tablo 2). Araştırma bulgusu Çapık ve ark.'nın (18.86 \pm 7.37$)$ ve Bacacı'nın (20.02 \pm 6.28$)$ çalışmasıyla paralellik göstermiştir $(7,20)$. Fakat Özyurt'un (11.59 \pm 4.21$)$ ve Çiltaş'ın $(23.66 \pm 7.48)$ çalışmaları araştırma bulgusundan düşük bulunmuştur $(19,21)$. Araştırmada gebelerin GYYKEÖ puan ortalaması (48.67 \pm 26.69$)$ Özorhan'ın (60.51 \pm 1.25$)$, Aksoy Derya ve ark. nın (74.1 \pm 2.7$)$ ve Karaçay Yıkar'ın (85.9 \pm 22.6$)$ çalışmasından düşük bulunmuştur $(25,26,27)$. Araştırma kapsamına alınan gebelerin gebelikte yaşanan yakınmaların ve bu yakınmaların yaşam kalitesi üzerine etkisinin fazla olmadığı söylenebilir.

Gebelerin TGDÖ ve GYYKEÖ puan ortalamaları arasındaki ilişkiye de bakılmıştır (Tablo 3). GYYKEÖ ile TGDÖ'nün Olumsuz Duygulanım alt boyutu puan ortalamaları arasında negatif yönde zayıf bir ilişki olduğu saptanmıştır. Aksoy Derya ve ark. nın çalışmasında kaygı ve stres ile GYYKEÖ arasında ( $r=-$ 0.164, $p=0.001$ ) anlamlı negatif bir ilişki bulmuşlardır (26). Yani gebelerin yakınmaları artıp yaşam kaliteleri azaldıkça olumsuz duygulanımları artmaktadır. Gebelikte meydana gelen olağan yakınmalar nedeniyle gebeler günlük yaşam aktivitelerini yerine getirememeleri ve zorlanmaları nedeniyle böyle bir sonuca varılmış olabilir.

GYYKEÖ ile TGDÖ'nün Eş Katııımı alt boyutu arasında pozitif yönde zayıf bir ilişki olduğu görülmüştür. Yani gebelerin algıladıkları eş desteği arttıkça gebelik yakınmalarını algılamadıkları ve yaşam kaliteleri artmaktadır. Çiltaş'ın çalışmasında eşiyle uyumlu olan gebelerin distres puanlarının (23.15 \pm 7.33$)$, bazen uyumlu olanlara $(26.65 \pm 7.86)$ göre daha düşük olduğu yani eş desteği olan gebelerin distres puanının daha düşük olduğu görülmüştür (21). Benzer şekilde Bacacı'nın ( $r=-0.109, p=0.019)$ çalışmasında da gebelerin eş desteğine ilişkin distresi azaldıkça kendini olumlu değerlendirmesinin arttığı görülmüştür (20). Araştırma bulgusundan farklı olarak Aksoy Derya ve ark. nın çalışmasında eş ilişkisi ile GYYKEÖ arasında ( $r=-0.005$, $p=0.918$ ) anlamlı bir ilişki bulunamamıştır (26).

GYYKEÖ ile TGDÖ'nün toplam puan ortalamaları arasında negatif yönde zayıf bir ilişki olduğu saptanmıştır. Yani gebelerin yakınmaları artıp yaşam kaliteleri azaldıkça distresi de artmaktadır. Benzer şekilde Kılıçarslan'ın (Kendall's tau_b=-0.315, $p<0.001)$ çalışmasında Durumluk Kaygı Düzeyi, Beck Depresyon skoru ile Yaşam Kalite skoru arasında negatif korelasyon olduğu görülmüştür (28).

Gebelerin tanııı özelliklerine göre TGDÖ puan ortalamalarının karşılaşıtıııması (Tablo 4) incelendiğinde; gebelerin gelir durumu, evlilik yılı, eş yaş, eş eğitim, eş çalışma durumu, gebelik, doğum, yaşayan çocuk sayısının Olumsuz Duygulanım alt boyutu puan ortalamalarını etkilediği bulunmuştur.

Gebelerin gelir durumu algısına göre TGDÖ'nün olumsuz duygulanım alt boyutu puan ortalaması arasındaki farkın istatistiksel olarak anlamlı olduğu görülmüştür. Gebelerin gelir durumu algısı iyileştikçe Olumsuz Duygulanım puan ortalamasının da arttığı görülmüştür. Gebelerin gelir durumu arttıkça sosyal ortamlarda bulunma intimalinde arttığı göz önüne alınırsa gebelerin; doğum, gebelik ve bebek bakımı gibi olumsuz hikâyelerinden etkilenmiş olabilecekleri düşünülmüştür.

Gebelerin evlilik yılına göre TGDÖ'nün Olumsuz Duygulanım alt boyutu puan ortalaması arasındaki farkın istatistiksel olarak anlamlı olduğu görülmüştür. Gebelerin evlilik yılı arttıkça Olumsuz Duygulanım puan ortalamasının da azaldığı görülmüştür. Evlilik yılı arttıkça kadınların gebelik, doğum deneyimleri artmakta olduğu düşünülmüş ve böylece tecrübe kazanarak gebelik, doğum ve bebek bakımı konusunda olumsuz düşünceler daha az yaşamış olabilirler. 
Gebelerin eşlerinin yaşlarına göre TGDÖ'nün Olumsuz Duygulanım alt boyutu puan ortalaması arasındaki farkın istatistiksel olarak anlamlı olduğu görülmüştür. Gebelerin eşlerinin yaşı arttıkça Olumsuz Duygulanım puan ortalamasının da azaldığı görülmüştür. Gebelerin eşlerinin yaşları arttıkça gebeliğe, doğuma ve çocuk bakımına yönelik paylaşılan konuların artması gebelerin puan ortalamalarının düşmesine neden olmuş olabilir.

Gebelerin eşlerinin eğitim durumu göre TGDÖ'nün Olumsuz Duygulanım alt boyutu puan ortalaması arasındaki farkın istatistiksel olarak anlamlı olduğu görülmüştür. Eşi üniversite mezunu olan gebelerin puan ortalamalarının en düşük olduğu görülmektedir. Eşinin eğitim durumu yüksek olan gebeler eşlerinden daha fazla destek alarak bu alt boyuttan düşük puan aldıkları düşünülmektedir.

Gebelerin eşlerinin çalışma durumu göre TGDÖ'nün Olumsuz Duygulanım alt boyutu puan ortalaması arasındaki farkın istatistiksel olarak anlamlı olduğu görülmüştür. Eşleri çalışmayan gebelerin puan ortalamasının çalışanlara göre daha düşük olduğu saptanmıştır. Eşi çalışmayan gebeler eşleri ile birlikte daha fazla vakit geçirdikleri için bu alt boyut puan ortalamalarının daha düşük olduğu tahmin edilmektedir.

Gebelerin gebelik, doğum ve yaşayan çocuk sayısına göre TGDÖ'nün Olumsuz Duygulanım alt boyutu puan ortalaması arasındaki farkın istatistiksel olarak anlamlı olduğu görülmüştür. Bu değişkenlere göre ikinci gebeliğini yaşayan ve bir doğum deneyimlemiş ve bir çocuğa sahip olan gebelerin puan ortalamaları en düşük bulunmuştur. Bu gebeler tahminen ilk gebeliklerini ve doğumlarını sorunsuz geçirmiş oldukları düşünülürse bu gebelikte de olumsuz duygulanım alt boyutundan düşük puan almış olabilirler.

Gebelerin tanıtıcı özelliklerine göre TGDÖ Eş Katıımı alt boyutu puan ortalamalarının karşılaştırıması (Tablo 4) incelendiğinde; gebelerin yaşı hariç geri kalan tüm değişkenlerin puan ortalamaları arasındaki farkın istatistiksel olarak anlamlı olduğu bulunmuştur $(p<0.05)$.

Gebelerin eğitim durumu göre TGDÖ'nün Eş Katııımı alt boyutu puan ortalaması arasındaki farkın istatistiksel olarak anlamlı olduğu görülmüştür. Gebelerin eğitim seviyesi arttıkça puan ortalamasının da azaldığı görülmüştür. Kadınların eğitim seviyesi artıkça iletişim becerilerinin, kendilerini ifade etme yeteneklerinin artığı göz önüne alııırsa; gebeler bu yeteneklerini kullanarak eşlerini gebeliklerine daha fazla dahil etmiş olabilirler. Bu nedenden dolayı Eş Katııımı disstres puanının düşük olduğu söylenebilir.
Gebelerin çalışma durumu göre TGDÖ'nün Eş Katılımı alt boyutu puan ortalaması arasındaki farkın istatistiksel olarak anlamlı olduğu görülmüştür. Çalışmayan gebelerin puan ortalamasının çalışanlara göre daha yüksek olduğu saptanmıştır. Çalışmayan gebeler çalışan gebelere göre daha fazla ev içi sorumluluklarına sahip olması nedeniyle bu alt boyuttan daha yüksek puan aldıkları söylenebilir.

Gebelerin yaşanılan yere göre TGDÖ'nün Eş Katıımı alt boyutu puan ortalaması arasındaki farkın istatistiksel olarak anlamlı olduğu görülmüştür. Yaşanılan yerin nüfusu artıkça gebelerin puan ortalamalarının düştüğü saptanmıştır. İlde yaşayan gebelerin sosyal ortamlarının fazla olması, ilişkilerinde paylaşımların fazla olması nedeniyle bu alt boyuttan ilde yaşayan gebeler düşük puan almış olabilir.

Gebelerin gelir durumu algısına göre TGDÖ'nün Eş Katıımı alt boyutu puan ortalaması arasındaki farkın istatistiksel olarak anlamlı olduğu görülmüştür. Gebelerin gelir durumu arttıkça eş katıımı alt boyut stres puanın düştüğü de görülmüştür. Gelir durumunun iyi olması eşler arasında ekonomik problemlerin az olmasına yada gebenin tüm intiyaçlarının erkekler tarafından karşılanması gebelerin puan ortalamasının düşmesine neden olmuş olabilir.

Gebelerin aile tipine göre TGDÖ'nün Eş Katılımı alt boyutu puan ortalaması arasındaki farkın istatistiksel olarak anlamlı olduğu görülmüştür. Çekirdek ailede yaşayan gebelerin geniş ailede yaşayan gebelere göre puanlarının daha düşük olduğu görülmüştür. Çekirdek ailede yaşayan gebeler genellikle tüm paylaşımlarını eşleriyle yaptıkları için eş katııımı stres puan ortalamasının daha düşük olduğu düşünülmektedir.

Gebelerin evlilik yılı ve eş yaşına göre TGDÖ'nün Eş Katııımı alt boyutu puan ortalaması arasındaki farkın istatistiksel olarak anlamlı olduğu görülmüştür. Gebelerin evlilik yılı ve eş yaşı arttıkça puan ortalamalarının da arttığı görülmüştür. Evliliğin ilk yıllarında genç baba adayları baba olmanın heyecanı ile gebeler ile daha fazla ilgilenmekte ve daha fazla paylaşımda bulundukları düşünülürse evlilik yılının artması ve yaşın ilerlemesi bu boyuttan algılanan stres puanının artmasına neden olmuş olabilir. Gebelerin eşlerinin eğitim durumu göre TGDÖ'nün Eş Katılımı alt boyutu puan ortalaması arasındaki farkın istatistiksel olarak anlamlı olduğu görülmüştür. Üniversite mezunu olan erkeklerin puan ortalamasının en yüksek olduğu saptanmıştır. Eşinin eğitim seviyesinin yüksek olması, gebelik, doğum ve yenidoğan bakımı gibi konulara daha fazla ilgi duymasına, araştırma yapmasına ve gebe ile birlikte kontrollere katıması vb. durumlardan dolayı üniversite mezunu grubun puan ortalamasının 
yüksek olduğu söylenebilir.

Gebelerin eş çalışma durumu göre TGDÖ'nün Eş Katıımı alt boyutu puan ortalaması arasındaki farkın istatistiksel olarak anlamlı olduğu görülmüştür. Eşi çalışmayan gebelerin puan ortalaması çalışanlardan yüksek bulunmuştur. Eşleri çalışmayan gebeler ekonomik kaygıları daha fazla yaşayacağı için bu alt boyuttan alınan puanında arttığı düşünülmektedir.

Gebelerin gebelik, doğum ve yaşayan çocuk sayısına göre TGDÖ'nün Eş Katııımı alt boyutu puan ortalaması arasındaki farkın istatistiksel olarak anlamlı olduğu görülmüştür. Bu değişkenlere göre ilk gebeliğini yaşayan ve hiç doğum deneyimi ve çocuk sahip olmayan gebelerin puan ortalamaları en düşük bulunmuştur. Bu gebelerin ilk gebeliği olması bu nedenle de eş desteklerinin fazla olduğu düşünülürse bu alt boyutundan düşük puan aldıkları söylenebilir.

Gebelerin tanıtıcı özelliklerine göre TGDÖ toplam puan ortalamalarının karşılaş̧ıııması (Tablo 4) incelendiğinde; yaşanılan yer, evlilik yılı, eş yaşı, eş eğitim durumu, eş çalışma durumu, gebelik sayısı, doğum sayısı ve yaşayan çocuk sayısı ölçek toplam puan ortalamasını etkilediği bulunmuştur.

Araştırmaya alınan köyde ve ilçede yaşayan gebelerin ilde yaşayan gebelere göre TGDÖ'nin puan ortalamasının daha yüksek olduğu görülmüştür. İI merkezinde yaşamak gebeler için bir avantaj olarak kabul edilmiş olabilir. Çünkü il merkezinde hastane, hekim, ebe ve hasta için gerekli olabilecek olanaklara ulaşma imkanının fazla olması kadınların TGDÖ puanının daha düşük çıkmasına neden olabilir.

Evliliklerinin ilk 5 yılında olan gebelerin TGDÖ puan ortalamasının diğer gebelere göre daha yüksek bulunmuştur. Bu gebeler muhtemelen ilk gebeliklerini yaşayan gebelerdir. Illk gebelikte yaşanan stres, depresyon vb. durumların daha fazla yaşanması gebeliğe dair herhangi bir tecrübenin olmamasındandır. Yaşanılan gebelik deneyimi arttıkça kadınlar bildikleri, deneyimledikleri olaylardan korkmayıp daha az endişe ve stres yaşamış olabilirler.

Gebelerin eşlerin yaşı artıkça puan ortalamasının düştüğü görülmüştür. Yaş ilerledikçe yaşanılan tecrübenin artması nedeniyle kadınların stres düzeyi azalmış olabilir.

Eş eğitim düzeyi ile TGDÖ puan ortalaması arasındaki farkın anlamlı ve eşi üniversite mezunu olanların puan ortalamasının daha düşük olduğu saptanmıştır. Araştırma bulgusuna paralel olarak Çiltaş'ın (21) çalışmasında eş eğitim durumuna göre TGDÖ'nün puan ortalaması arasındaki farkın anlamlı olduğu görülmüştür. Fakat Çapık ve ark. (7) çalışmasında ise eş eği- tim düzeyi ile TGDÖ puan ortalaması arasındaki farkın anlamlı olmadığı fakat eşi üniversite mezunu olanların puan ortalamasının daha düşük olduğu bulunmuştur. Bu bulgu ile çalışma bulgumuz benzerlik göstermektedir. Bu durum; eş eğitim düzeyinin yüksek olması gelir getiren bir işe sahip olması aynı zamanda sosyo-ekonomik gücün yüksek olmasına ve eşin gebeyi daha iyi anlayıp destek olması ile açıklanabilir. Bunun doğal sonu olarak gebelerin eşinin eğitim seviyesi yüksek olanların distreslerinin düşük olması beklenen bir sonuçtur.

Gebelerin eşlerinin çalışma durumuna göre TGDÖ'nin puan ortalamaları arasındaki fark anlamlı bulunmuştur. Benzer şekilde Faisal Cury ve Menezes (29) çalışmalarında eş çalışma durumu ile anksiyete ve depresyon puan ortalamaları arasında istatistiksel olarak anlamlılık tespit etmişlerdir. Araştırma bulgusundan farklı olarak Çiltaş'ın (21) çalışmasında eşin çalışma durumu TGDÖ puan ortalaması arasındaki farkın anlamlı olmadığı görülmüştür.

Araştırmada gebelik sayısı ile TGDÖ puan ortalaması arasında anlamlı farklııı olduğu bulunmuştur. Benzer şekilde Çiltaş'ın (21) çalışmasında gebelik sayısı ile TGDÖ puan ortalaması arasındaki fark anlamlı olarak saptanmıştır. Literatürde gebelik sayısı ile depresyon ve anksiyete puanlarının arttığını, depresyon sıklığı ve şiddeti arasında anlamlı ilişki olduğu ve prenatal distres arasında anlamlı bir ilişki olduğu da saptanmamıştı $(13,29-31)$. Fakat Çapık ve ark. (7) çalışmasının bulgusu araştırma bulgusuna benzememektedir.

Araştırmada doğum sayısı ile TGDÖ puan ortalaması arasında anlamlı farklılık olduğu bulunmuştur. Çiltaş'ın (21) çalışmasında canlı doğum sayısı ile TGDÖ puan ortalaması arasında pozitif yönde bir ilişki bulunmuştur. Çalışmada üç ve daha fazla sayıda doğum yapan kadınların distresi en yüksek bulunmuştur. Doğum sayısı artıkça kadının yaşının ilerlediği ve hem kendi sağlığı hemde bebeğin sağlığından endişelenerek distreslerinin yüksek çıktığı düşünülebilir.

Çalışma sonucuna göre yaşayan çocuk sayısı ile TGDÖ puan ortalaması arasında istatistiksel olarak anlamlı bir fark olduğu belirlenmiştir. Çiltaş'ın (21) çalışma sonucu ile araştırma bulgusu benzerdir. Literatürde yaşayan çocuk sayısı artııça depresyon ve anksiyete puanlarının arttığını belirtilmiştir $(32,33)$. Çapık'ın (7) çalışma sonuçları ile araştırma bulgusu benzerlik göstermemiştir.

Gebelerin tanıtıcı özelliklerine göre GYYKEÖ puan ortalamaIarının karşılaştırımasına göre çalışma durumu, gelir durumu algısı, aile tipi, evililik yılı, eş yaş, eş eğitim, eş çalışma durumu puan ortalamaları arasındaki farkın istatistiksel olarak anlamlı 
olduğu görülmüştür (Tablo 5). Araştırma bulgusundan farklı olarak Aksoy Derya ve ark. nın çalışmasında sadece eğitim değişkenin etkileyen faktör olduğu görülmüştür (26).

Araştırmada kendisi ve eşi çalışan gebelerin yaşam kalitesinin çalışmayan gebelerden daha iyi olduğu görülmüştür. Herhangi bir işte çalışma ile sosyal güvencenin bulunması, ekonomik özgürlüğünün olması ve sağlık hizmetlerine daha kolay ulaşıyor olması bu farkın sebebi olabilir.

Gebelerin gelir durumu algısı arttıkça yaşam kalitelerinin de arttığı görülmüştür. Ekonomik durum sağlık hizmetlerine ulaşmayı kolaylaştırdığı için gebeliğe bağlı yakınmalar nedeniyle sağlık hizmetlerine ulaşamayan, bilgi almayan gebelerin yaşam kalitesi olumsuz etkilenmemiş olabilir.

Geniş ailede yaşayan gebelerin yaşam kalitesinin çekirdek ailede yaşayan gebelerden daha yüksek olarak saptanmıştır. Geniş ailede yaşayan gebeler günlük işlerini, yaşamsal sorumluluklarını diğer aile üyeleri ile paylaştıkları için gebelerin yaşam kaliteleri olumsuz yönde etkilenmemiş olabilir.

Çalışmadaki gebelerin evlilik yılı ve eş yaşı artıkça yaşam kalitesinin düştüğü görülmüştür. Evililik yııının ve eş yaşının artması ile beraber evdeki çocuk sayısının artması, ev içi sorumlulukların artması gebelerin yaşam kalitesini azaltmış olabilir.

Gebelerin eşlerinin eğitim seviyesi artıkça yaşam kalitesinin düştüğü görülmüştür. Eğitim seviyesi yüksek olan erkeklerin daha fazla işleri ile meşgul olmaları ve gebelere destek olmak için yeteri kadar vakit ayıramadıkları için bu sonuç çıkmış olabilir. Araştırma bulgusuna benzer olarak Kılıçarslan'nın (Kendall's tau_b $=0.585$, $p<0.001$ ) çalışmasında gebelerin eşlerinin eğitim durumu ile Yaşam Kalitesi skoru arasında bir ilişki saptanmıştır. Fakat aynı çalışmada gebenin yaşı, gebenin eğitim durumu, evlilik süresi, ailenin ortalama aylık geliri, evde sürekli yaşayan kişi sayısı, çocuk sayısı, gebelik haftası, doktor takiplerinin sıkı̆̆ı, ebelerin ev ziyareti sıklığı ile Yaşam Kalitesi Ölçeği arasında korelasyon görülmemiştir (28).

Gebelerin TGDÖ kesme noktasına göre dağıımı (Tablo 6) incelendiğinde; gebelerin az bir kısmında distres görülmüştür. Bu bulgu Çapık (\%11.9) ve Bacacı'nın (\%13.1) çalışmasına benzemektedir $(7,20)$. Fakat Çiltaş'ın (\%33.0) bulgusu araştırma bulgusundan yüksektir (21).

\section{SONUÇ VE ÖNERILER}

Gebelikte yaşanan distres ve gebelikteki yakınmalar-yaşam kalitesi arasındaki ilişkinin incelenmesi amacıyla yapılan çalışmada; gebelerin TGDÖ'den aldıkları puan ortalamasına göre az sayıda gebede distres bulunmuştur. Gebelerin yaşam kaliteleri- nin iyi olduğu saptanmıştır. Gebelerin yakınmaları artıp yaşam kaliteleri azaldıkça olumsuz duygulanımlarının ve distreslerinin artmakta olduğu görülmüştür. Gebelerin algıladıkları eş desteği artıkça gebelik yakınmalarını algılamadıkları ve yaşam kalitelerinin arttığı bulunmuştur. Gebelerin distresi artııça yaşam kalitesinin de azaldığı saptanmıştır.

\section{Bu sonuçlar göz önünde bulundurularak;}

- $\quad$ Ebeler tarafindan gebelikte meydana gelen fizyolojik, biyokimyasal ve psikolojik değişiklikler konusunda gebelere ve eşlerine bilgilendirici eğitimlere daha fazla yer verilmesi,

- Gebelikte meydana gelen olağan yakınmaların geçici olduğu konusunda ebelerin, gebeleri bilinçlendirmesi ve desteklemesi ve alınması gereken önlemleri öğretmesi,

Ülkemizde gebelerin gebelikte meydana gelen yakınmalar ve bu yakınmaların yaşam kalitesi, distres düzeyine etkisinin belirlenmesi için farklı örneklem gruplarında daha fazla çalışma yapılması,

önerilebilir.

Çalışma 29 Kasım- 1 Aralık 2018 tarihleri arasında yapılan Uluslararası Sağlık Bilimleri Kongresinde sözel bildiri olarak sunulmuştur.

\section{KAYNAKLAR}

1. Taşkın L. Doğum ve Kadın Sağlığı Hemşireliği Kitabı, 13.Baskı. Ankara, Özyurt Matbaacılık, 2016: 103-19.

2. Taşpınar A. Normal Gebelik. İçinde: Ahsen Ş (editör). Kadın Sağlığı, 1. Baskı. İstanbul, Bedray Basın Yayıncılık, 2008: 454.

3. Yamaç K, Gürsoy R, Çakır N. Gebelik ve Sistemik Hastalıklar. İstanbul, Nobel Tıp Kitabevi, 2002: 1-8.

4. Lowdermilk DL, Perry SE. Maternity Nursing, 6 th ed. China. Mosby, 2003: 166-91.

5. Aydemir H. Maternal Obezitenin Gebelikte Oluşan Yakınmalara ve Özbakım Gücüne Etkisi. Sağlık Bilimleri Enstitüsü, Ebelik Ana Bilim Dalı. Yüksek Lisans tezi, Aydın: Adnan Menderes Üniversitesi, 2014.

6. Altıçelep F. Gebelerdeki Prenatal Distres Düzeyinin Belirlenmesi. Sağlık Bilimleri Enstitüsü, Hemşirelik Ana Bilim Dalı. Yüksek Lisans Tezi, İstanbul: İstanbul Bilim Üniversitesi, 2011.

7. Çapık A, Apay ES, Sakar T. Gebelerde distres düzeyinin belirlenmesi. Anadolu Hemşirelik ve Sağlık Bilimleri Dergisi 2015, 3:196-203. 
8. Terzioğlu F. Ebeveynliğe Hazırlanma ve Doğum Öncesi Bakım. İçinde: Taşkın L (editör). Doğum ve Kadın Sağlığı Hemşireliği, 13. Baskı. Ankara, Özyurt Matbaacılık, 2016:183,203-15.

9. Doyurgan KT. Gebelik ve Gebelik Sonrası Dönemdeki Kadınların Uyum Düzeyleri. Sosyal Bilimler Enstitüsü, Eğitim Bilimleri. Yüksek Lisans Tezi, Samsun: Ondokuzmayıs Üniversitesi, 2009.

10. Furber CM, Garrod D, Maloney E, Lovell K, McGowan L. A qualitative study of mild to moderate psychological distress during pregnancy. International Journal of Nursing Studies, 2009, 46: 669-77.

11. Schuurmans C, Kurrasch DM. Neuro developmental consequences of maternal distress: what do were all know? Clinical Genetics, 2013, 83:108-17.

12. Gözüyeşil YE, Şirin A, Çetinkaya Ş. Gebe kadınlarda depresyon durumu ve bunu etkileyen etmenlerin incelenmesi. Fırat Sağlık Dergisi. 2008, 9: 40- 66.

13. Vırıt $O$, Akbaş E, Savaş AH, Sertbaş $G$, Kandemir $H$. Gebelikte depresyon ve kaygı düzeylerinin sosyal destek ile ilişkisi. Nöropsikiyatri Arşivi. 2008, 45: 9-13.

14. Savrun M. Gebelik ve depresyon. Klinik Gelişim. 2008, 21: $165-66$.

15. Huizink AC, Mulder EJ, Robles de Medina PG, Visser $\mathrm{GH}$, Buitelaar JK. Is pregnancy anxiety a distinctive syndrome? Early Human Development, 2004, 79:81-91.

16. Marakoğlu K, Şahsıvar MŞ. Gebelikte depresyon. Türkiye Klinikleri Journal of Medical Sciences, 2008, 28:525-32.

17. Sevindik F. Elazığ Ilinde Gebelikte Depresyon Prevelansı ve Etkileyen Faktörler. Sağlık Bilimleri Enstitüsü, Halk Sağı̆̆ı Anabilim Dalı. Yüksek Lisans Tezi, Elazığ: Fırat Üniversitesi, 2005.

18. Çağlar M. Gestasyonel Diyabetli Kadınlarda Prenatal Distres ve Depresyon Düzeylerinin Belirlenmesi. Sağlık Bilimleri Enstitüsü. Kadın Sağığı ve Hastalıkları Hemşireliği Anabilim Dalı. Yüksek Lisans tezi, İstanbul: İstanbul Üniversitesi, 2017.

19. Özyurt Ç, Güzel y. Anne Adayının Psikobiyolojik Mizacı İle Yaşadığı Distres Düzeyleri Arasındaki llişki. Biruni Üniversitesi Sağlık ve Eğitim Bilimleri Dergisi, 2018, 1:1-15.

20. Bacacı H, Ejder Apay S. Gebelerde beden imajı algıSı ve distres arasındaki ilişki. Düzce Üniversitesi Sağık Bilimleri Enstitüsü Dergisi. 2018; 8: 76-82.

21. Çiltaş NY, Tuncer S. Gebelikte Distresin Tanımlanması: Erzincan Örneği. MAKÜ Sağ. Bil. Enst. Derg. 2019, 7:15-24.
22.

Pop VJM, Pommer AM, Pop-Purceleanu M, Wijnen HAA, Bergink V, PouweR F. Development of the Tilburg Pregnancy Distress Scale: the TPDS. BMC Pregnancy and Childbirth, 2011, 11:80-87.

23. Çapık A. Pasinlioğlu T. Validity and reliability study of the Tilburg Pregnancy Distress Scale into Turkish. Journalof Psychiatric and Mental Health Nursing 2015, 22:260-9.

24. Foxcroft KF, Callaway LK, Byrne NM, Webster J. Development and validation of a pregnancy symptoms inventory. BMC Pregnancy and Childbirth, 2013, 13:1-9.

25. Özorhan YE. Gebelikte Yakınmalar ve Yaşam Kalitesine Etkisi Ölçeğinin Geçerlilik ve Güvenilirlik Çalışması. Sağık Bilimleri Enstitüsü, Doğum, Kadın Sağlığı ve Hastalıkları Hemşireliği Anabilim Dalı. Doktora tezi, Erzurum: Atatürk Üniversitesi, 2016.

26. Derya YA, Özşahin Z, Uçar T, Erdemoğlu Ç, Ünver H. Gebelikteki Yakınmaların Yaşam Kalitesine Etkisi ile Psikososyal Sağlık Düzeyi Arasındaki Ilişkinin İncelenmesi. TJFMPC, 2018, 12: 171-177.

27. Yıkar Karaçayır S. Doğum Öncesi Dönemde Verilen Eğitimin Gebelikte Görülen Yakınmalar Ve Yaşam Kalitesine Etkisi. Sağlık Bilimleri Enstitüsü, Yükseklisans tezi, Hemşirelik Anabilim Dalı. Adana: Çukurova Üniversitesi, 2017.

28. Kılıçarslan S. Edirne Şehir Merkezindeki Son Trimester Gebelerin Sosyodemografik Özellikleri, Yaşam Kaliteleri, Kaygı Düzeyleri. Tıp Fakültesi, Aile Hekimliği Anabilim Dalı, Uzmanlık tezi, Trakya: Trakya Üniversitesi, 2008.

29. Faisal Cury A., Menezes PR. Prevalence of anxiety and depression during pregnancy in a private setting sample. Archives of Women's Mental Health. 2007;10, 25-32.

30. Çakır L, Can H. Gebelikte sosyodemografik değişkenlerin anksiyete ve depresyon düzeyleri ile ilişkisi. Turkish Family Physician, 2014, 3:35-42.

31. Çelik F., Nadirgil Köken G. ve Yılmazer M. Gebelikte depresyon semptomlarının sıklığı ve depresyon gelişimini etkileyen faktörler. Anadolu Tıbbi Araştırmalar Dergisi, 2013; 7, 110117.

32. Karataylı S, Gezginç K, Uguz F, Karataylı R, Çilli S, The Comparison of depression, anxiety and quality of life levels amoung trimesters of pregnancy. 2010 GORM; 16:79-89.

33. Arslan B. Gebelerde anksiyete ve depresyonla ilişkili sosyodemografik özellikler. Tıp Fakültesi, Uzmanlık tezi, Isparta: Süleyman Demirel Üniversitesi, 2010. 